\title{
The 1898 American Cereal Company Strike in Cedar Rapids: Gender, Ethnicity, and Labor in Late Nineteenth-Century Iowa
}

\author{
PAM STEK
}

ON OCTOBER 25, 1898, approximately 100 female employees on strike at the American Cereal Company in Cedar Rapids met with company manager George McDonald to press their demands for higher wages and improved working conditions. ${ }^{1}$ After McDonald refused to discuss new terms, the women visited their old work room and accosted the workers who had been hired to take their places. The strikers disregarded the foreman's orders to leave the premises and instead began throwing supplies out the windows, tearing open packages of oatmeal, and verbally abusing strikebreakers. ${ }^{2}$ Newspapers throughout the Midwest picked up the story of the "riotous girl strikers" who "play[ed] havoc" in the

\footnotetext{
I gratefully acknowledge a grant from the State Historical Society of Iowa that supported my research on this article. I am also grateful to Marvin Bergman and the Annals of Iowa's anonymous reviewers for their thoughtful and helpful comments.

1. The strike began on October 22, but the striking workers' first meeting with McDonald did not occur until October 25. Newspaper accounts varied on the exact number of women on strike. Some reports put the number at 135, while others gave a less precise total of approximately 100.

2. "Could Not Agree," Cedar Rapids Evening Gazette (hereafter cited as Gazette), $10 / 25 / 1898$.
}

THE ANNALS OF IOWA 74 (Spring 2015). (C) The State Historical Society of Iowa, 2015. 
cereal mill's packaging room. ${ }^{3}$ The women's "violent" behavior made for exciting copy, but few newspapers outside Cedar Rapids covered the rest of the story. The day after the confrontation, striking workers switched to the more peaceful tactic of petitioning the city council to revoke the mill's tax-exempt status. Though less sensational than attacks on company property, the women's use of political pressure had the desired effect. On October 27, the American Cereal Company agreed to meet the women's terms and reinstated the striking workers.

The 1898 strike of American Cereal Company workers is exceptional for several reasons. The strike was orchestrated and conducted by women workers alone, without the benefit of formal union leadership or support. During the ten-year period between 1895 and 1905, only 83 of the almost 16,000 strikes ordered by labor organizations nationwide (less than 0.5 percent), were conducted entirely by women workers. In only 35 of those 83 strikes (42 percent), did female strikers fully succeed in winning their demands. ${ }^{4}$ The women cereal workers' victorious campaign represents an exceptional example of a successful femaleorganized strike in the late nineteenth century.

3. See, for example, "Girl Strikers in Iowa Play Havoc in an Offending Plant," Chicago Tribune, 10/25/1898; "Girl Strikers Violent," Milwaukee Journal, 10/25/ 1898; "Riotous Girl Strikers," Logansport (IN) Journal, 10/26/1898; and "Girls on a Strike," Eau Claire (WI) Weekly Telegram, 10/27/1898. The quotation is taken from the Logansport Journal.

4. John B. Andrews and W. D. P. Bliss, History of Women in Trade Unions (1911; reprint, New York, 1974), 204-7. These statistics include only those strikes ordered by labor organizations. In 1900, approximately 20 percent of women in the United States worked for wages outside the home, but only about 3 percent of women engaged in industrial occupations were members of trade unions. Given the low number of female union members, it is likely that the incidence of strikes conducted by women unaffiliated with labor organizations was higher than that of strikes carried out under union auspices. See S. Jay Kleinberg, "Women in the Economy of the United States from the American Revolution to 1920," in Retrieving Women's History: Changing Perceptions of the Role of Women in Politics and Society, ed. S. Jay Kleinberg (New York, 1988); Alice Kessler-Harris, Out to Work: A History of Wage-Earning Women in the United States (New York, 1982), 152. The statistic cited by Andrews and Bliss for successful women's strikes is lower than that for all strikes (including men and women workers) ordered by labor organizations during the 25-year period from 1881 to 1905, when 49 percent of such strikes fully succeeded. See U.S. Bureau of Labor, Twenty-first Annual Report of the Commissioner of Labor, 1906, Strikes and Lockouts, (1907), 36-37, at http:/ / congressional.proquest.com.proxy.lib.uiowa.edu/congressional/docview/t47.d48.5213 _h.doc.822?accountid=14663 (accessed 5/20/2014). 
The women's triumph demonstrates that despite their lack of formal trade union organization, the female strikers were not "unorganized." Their mobilization and strategies evinced familiarity with and embrace of the techniques of organized labor: development and maintenance of group solidarity, clear articulation of specific grievances, cultivation of community support, and the demand to negotiate directly with company management over the terms of employment. Historians of women's labor tend to highlight women's efforts to establish and maintain permanent trade union organizations and often equate labor militancy with union membership. ${ }^{5}$ Although such scholarship makes an invaluable contribution to our understanding of women's labor, it does not address the experiences and concerns of the vast majority of working women who did not join unions but nevertheless publicly agitated for redress of work-related grievances. ${ }^{6} \mathrm{~A}$ focus on trade union organization downplays the importance of women's labor activism conducted without the assistance of a recognized union. Describing such activism as "spontaneous" or "emotional" overlooks the commitment and organization required to mobilize and maintain cohesion among a group of strikers unconnected by formal institutional organization. ${ }^{7}$ Analyzing episodes of women's "unorganized" labor activism provides insight into how the majority of female workers - those who did not join

5. See, for example, Stephen H. Norwood, Labor's Flaming Youth: Telephone Operators and Worker Militancy, 1878-1923 (Urbana, IL, 1990); Dorothy Sue Cobble, Dishing It Out: Waitresses and Their Unions in the Twentieth Century (Urbana, IL, 1991); Carole Turbin, Working Women of Collar City: Gender, Class, and Community in Troy, New York, 1864-86 (Urbana, IL, 1992). In her analysis of almost 50 strikes between 1886 and 1903, all of which involved both male and female workers, Ileen DeVault discusses only one that did not involve formal trade union participation. See DeVault, " 'Too Hard on the Women, Especially': Striking Together for Women Workers' Issues," International Review of Social History 51 (2006), 441-62.

6. Alice Kessler-Harris estimates that only 3.3 percent of women employed in industrial occupations in 1900 belonged to trade unions. That figure fell even further in the following decade, reaching a low of 1.5 percent in 1910. See KesslerHarris, Out to Work, 152.

7. Leslie Woodcock Tentler, Wage-Earning Women: Industrial Work and Family Life in the United States, 1900-1930 (New York, 1979), 78; Venus Green, Race on the Line: Gender, Labor, and Technology in the Bell System, 1880-1980 (Durham, NC, 2001), 90, 105; Suellen Hoy, “The Irish Girls' Rising: Building the Women's Labor Movement in Progressive-Era Chicago," Labor: Studies in Working-Class History of the Americas 9 (2012), 77-100. 
trade unions - viewed their labor and the strategies they employed to achieve their ends.

The 1898 strike in Cedar Rapids is also unusual because local newspapers took seriously the strikers' cause. Newspaper reporters interviewed strikers' representatives, reported the women's concerns, and provided in-depth coverage of the strikers' meetings and activities. This level of media attention was unusual in an era when newspaper editors and reporters tended to ignore or minimize the grievances of female workers. The largest and most widely publicized strike of women workers in the early twentieth century was the 1909-1910 shirtwaist strike in New York City, when 20,000 women walked off their jobs in hundreds of factories. During that four-month-long labor dispute, the popular press printed only one article authored by a striking worker and carried only very brief quotes from striking women. ${ }^{8}$ In contrast, the week-long strike of approximately 100 women in Cedar Rapids garnered extensive local coverage, with daily reports focused on the women's grievances and strategies.

The 1898 women cereal workers' strike provides historians with rare insight into women workers' efforts to improve their labor conditions and economic security, their self-identification as skilled workers, and their ability to organize a successful strike campaign. American Cereal Company managers tried to discourage and intimidate the female strikers with a variety of tactics, including hiring strikebreakers and publicly disparaging the character of Bohemian immigrants, an ethnic group from which many of the cereal company's employees were drawn. The strikers also faced the dominant societal view that devalued women's wage labor and often cast suspicions on workers' attempts to

8. Nan Enstad, Ladies of Labor, Girls of Adventure: Working Women, Popular Culture, and Labor Politics at the Turn of the Twentieth Century (New York, 1999), 8487. Similarly, during the 1909-1910 strike of shirtwaist workers in Philadelphia, only a fraction of the articles published in local newspapers acknowledged workers' grievances. Instead, the Philadelphia media framed the strikers and their union as instigators of violence and blamed outside agitators, not difficult and dangerous working conditions, for the labor unrest. See Julianne Kornacki, "Revealing Division: The Philadelphia Shirtwaist Strike, the Jewish Community, and Republican Machine Politics, 1909-1910," Pennsylvania History 80 (2013), 376. 
organize. ${ }^{9}$ In the same decade that witnessed union defeats at steel mills in Homestead, Pennsylvania, in 1892 and in the nationwide railway strike of 1894, the striking women in Cedar Rapids galvanized community support for their cause and shrewdly turned to their advantage public perceptions of the cereal company's unfair manipulation of city tax policy. Elsewhere in the nation, state and local governments offered military and judicial assistance to employers during periods of labor unrest, but in Cedar Rapids female strikers claimed the right to appeal to city leaders for help in their fight for higher wages and better working conditions. Using legal and political strategies, the young women cereal workers prevailed against ethnic discrimination and powerful company resistance in their efforts to shape the conditions of their employment and to gain recognition as competent and serious workers.

BY THE END of the nineteenth century, the American Cereal Company was the largest oatmeal producer in the nation and one of the largest employers in Cedar Rapids. Canadian émigrés John Stuart and his son Robert, along with Cedar Rapids businessman George Douglas, established the North Star Oatmeal Mills in the city in 1873 . The quality and quantity of oats grown in the region, an abundance of skilled labor, and an advantageous location on the Cedar River all contributed to the mill's swift growth as part of the rapidly expanding cereal industry. George Douglas and Robert Stuart expanded their holdings in 1879 to include the Imperial Mill in Chicago and eventually moved the company's business headquarters to that city. In 1891 Stuart negotiated the inclusion of the Stuart and Douglas mills into a trust made up of the seven largest oatmeal manufacturers in the country, united as the American Cereal Company with head- quarters in Akron, Ohio. The Cedar Rapids mill was the second-largest of the trust's

9. For a discussion of attitudes toward women's labor in the late nineteenth century, see Kessler-Harris, Out to Work, 75-214. Sharon Wood analyzes women's work in Davenport, another eastern Iowa city, in the late nineteenth century and demonstrates that working women's efforts to negotiate urban territory and shape public policy were opposed by men who wanted to maintain the gendered boundaries of public spaces. See Wood, The Freedom of the Streets: Work, Citizenship, and Sexuality in a Gilded Age City (Chapel Hill, NC, 2005). 
cereal producers. By 1901 the company employed 600 workers in Cedar Rapids, and mill management was planning to increase its capacity by 250 percent. ${ }^{10}$

The company used its status as one of the city's major employers to obtain tax concessions from the city government. At a city council meeting on May 21, 1895, representatives of the American Cereal Company requested a ten-year exemption from city taxation. In its petition, the company stated that it had "become necessary to either enlarge the plant at Cedar Rapids or procure another plant farther west." These improvements, the company argued, "will cost a large sum of money and furnish work for a large increase of employees ... to say nothing about the employment of a large number of resident mechanics" to construct the proposed new buildings. Claiming its status as one of the city's largest employers and threatening to move its operations elsewhere proved an effective strategy for the company. Although some aldermen opposed the tax exemption and others argued for a reduced period of five years, in the end the city council approved the company's petition for a ten-year release from city taxes. ${ }^{11}$

In addition to securing favorable tax provisions, the American Cereal Company relied on labor provided by a diverse group of employees to expand its operations and increase its profitability. The city had an immigrant population that included migrants from Ireland, Germany, and Scotland, but in the late 1890s, Bohemian immigrants from the Austro-Hungarian Empire represented the largest ethnic group in Cedar Rapids. ${ }^{12}$ Bohemian settlers had begun arriving in the city and surrounding areas in the

10. Harrison John Thornton, The History of the Quaker Oats Company (Chicago, 1933), 37-70; Janette Stevenson Murray and Frederick Gray Murray, The Story of Cedar Rapids (New York, 1950), 106-9; Arthur F. Marquette, Brands, Trademarks, and Good Will: The Story of the Quaker Oats Company (New York, 1967), 3477; "Our Greatest Home Industry," Gazette, 1/1/1901.

11. “Taxes Are Rebated," Gazette, 5/22/1895.

12. In late nineteenth-century Cedar Rapids, English-language newspapers referred to immigrants from the lands of the Czech Republic as "Bohemian" even though some had emigrated from Moravia or other regions. Despite its imprecision, I follow the contemporary usage of the term. For a discussion of the origins of Czech immigrants in Cedar Rapids, see Martha E. Griffith, "Bohemian Settlement in Cedar Rapids" (M.A. thesis, University of Wyoming, 1942), 6-21. 
early 1850s. Many of them fled central Europe after the failed revolutions of 1848. The later decades of the century witnessed a shift in the number and occupations of Bohemian immigrants. Whereas the earlier Bohemian immigrant stream tended to be small and made up of farmers and artisans, after about 1880 the number of Bohemian immigrants increased and a greater percentage worked as laborers, attracted by the city's growing industrial sector. By one historian's estimation, by the early decades of the twentieth century people of Bohemian descent came to represent one-fourth of the city's population. Many Bohemian laborers found employment with the American Cereal Company. In 1898 approximately one-fourth of the mill's employees were Bohemian immigrants or their offspring. ${ }^{13}$

Despite their contributions to the city's economy, during the last decades of the nineteenth century Bohemian immigrants struggled to overcome widespread prejudice against eastern Europeans. Bohemian immigrants faced particularly harsh censure after the 1886 Haymarket Massacre in Chicago. To reporters who equated recent immigrants with bomb-throwing anarchists, Bohemian immigrants represented a significant threat to national security. Reporting on events in Chicago, Cedar Rapids newspapers carried stories of rioting Bohemian workers parading under the red flag of socialism and attacking police officers. ${ }^{14}$ The Cedar

13. Griffith, "Bohemian Settlement in Cedar Rapids," 6-9, 24-26; The Federal Writers' Project, Works Progress Administration, State of Iowa, Guide to Cedar Rapids and Northeast Iowa (Cedar Rapids, 1937), 22; Luther A. Brewer and Barthinius L. Wick, History of Linn County, Iowa, from Its Earliest Settlement to the Present Time, 2 vols. (Chicago, 1911), 1:121-23. The estimate of Bohemian immigrants employed at the American Cereal Company is based on an analysis of 352 company workers listed in the Gazette's 1898 city directory. See Cedar Rapids City Directories (1890-1898), 1898-05-01, Digital Archives of the Marion Public Library, http://mpl.newspaperarchive.com/1890-1899. Of these 352 employees, 97 (28 percent) had Bohemian surnames. These totals may not be precise, since some individuals employed at the mill may not have been listed in the directory and some surnames may have been misidentified. However, an enumeration of 352 employees in 1898 appears to be consistent with the 600 employees the Gazette reported in 1901. In 1898 the mill undertook a significant enlargement of its facilities that would have led to a sizeable increase in the number of its employees by 1901. See "Our Greatest Home Industry," Gazette, $1 / 1 / 1901$.

14. "Mangled Blue-Coats," Cedar Rapids Standard (hereafter cited as Standard), $5 / 13 / 1886$. 
Rapids Weekly Times charged that "the participants in the murderous riots were ... Poles, Bohemians, and Italians" and opined that if socialist immigrants "do not like free America, let them go back to the despotic countries from which they came. They are not fit to be American citizens." The Times reprinted an editorial from the Iowa Falls Sentinel, calling "sound" and "wise" the Sentinel editor's diatribe against the "importation of red-mouthed Poles, Bohemians, and other foreign classes whose whole carcasses are impregnated with socialistic and nihilistic blood and taint, and who have no higher appreciation of our institutions and liberties than so many hyenas fresh from their native jungles." 15 In the eyes of those who espoused such nativist sentiments, the alleged affiliation of Bohemian immigrants with anarchism and socialism marked them as primitive savages unfit for U.S. citizenship. ${ }^{16}$ Bohemian immigrants contested these allegations in the pages of local newspapers and denied any connection with anarchism, referencing their long years of residence in the United States, their high rates of home ownership, and the leading of "industrious, frugal, and honest lives" as proof of their worthiness as law-abiding citizens. ${ }^{17}$

15. “The Socialistic Spawn," Cedar Rapids Weekly Times (hereafter cited as Times), 5/13/1886; "Sound on the Strike Question," Times, 5/20/1886. The Times later retracted its blanket condemnation of Bohemian immigrants, conceding that Bohemian immigrants in Cedar Rapids were industrious, thrifty, and law-abiding. See "Defends the Bohemians," Times, 6/3/1886.

16. Characterizing Bohemian immigrants as animals and savages also served to call into question their racial status, since native-born whites often used such derogatory language when referring to African Americans and Native Americans. In the late nineteenth century, the racial status of new immigrants was ambiguous. Their light skin offered the promise, but not the guarantee, of inclusion in the "white" race. From 1840 until 1924, mass European migration led to a fracturing of whiteness into a hierarchy of multiple, and often contested, categories of "white" races. Early twentieth-century conceptions of race were rooted not necessarily in skin color but nevertheless in assumptions of inherent difference. Deficiencies ascribed to new immigrants were often connected to their perceived fitness for certain types of jobs or for citizenship, much as they were for people of color but at different levels of intensity and permanence. See Matthew Frye Jacobson, Whiteness of a Different Color: European Immigrants and the Alchemy of Race (Cambridge, MA, 1998); and David R. Roediger, Working towards Whiteness: How America's Immigrants Became White: The Strange Journey from Ellis Island to the Suburbs (New York, 2006).

17. "Not the Bohemians," Standard, 5/20/1886; "Bohemian Americans," Gazette, 5/25/1886; "Defends the Bohemians," Times, 6/3/1886. 
As nativists' calls for immigration restriction intensified nationwide in the 1890s, Bohemian immigrants faced increasingly harsh denunciations of their ability to contribute to American society. In February 1891, at a Knights of Labor meeting in Des Moines, Iowa Secretary of State J. M. McFarland called for restrictions on the entry into the United States of "Dagos, Huns, and other undesirable immigrants" from the lands of the AustroHungarian Empire. In his speech, McFarland quoted from a report written by the U.S. Consul-General to Austria, who described Bohemian laborers as "violent ultra-socialists" and "illiterate and ignorant in the extreme." Bohemian immigrant and Cedar Rapids resident L. J. Palda, in open letters published in both the Cedar Rapids Standard and the Cedar Rapids Evening Gazette, disputed McFarland's "racial prejudice and ignorance." Palda was an influential socialist journalist and labor organizer who in the 1890s earned his living as a cigar maker in Cedar Rapids. In his letters to the editor, Palda pointed to Bohemians' industriousness, high rates of literacy in their native language, and their support of moderate labor reform as evidence of their willingness and ability to participate in U.S. institutions and politics. ${ }^{18}$

Many Bohemian immigrants became actively involved in city and state politics to further establish their claims to citizenship. At least one Bohemian immigrant served as a Cedar Rapids alderman from 1883 to 1900, and in 1898 Bohemians were appointed as fire chief and sewer inspector for the city. ${ }^{19} \mathrm{~J}$. M. B. Letovsky, the founder of one of the city's first Bohemian newspapers, Slovan Americky, served as mayor of nearby Iowa City before moving to Cedar Rapids and was elected to the state legislature in $1890 .{ }^{20}$

18. "McFarland Replies," Gazette, 2/24/1891; "Calling Him Down," Gazette, 2/19/1891; "Palda Replies," Standard, 3/5/1891; "The First Number," Gazette, 9/8/1892. For more on Palda, see Thomas Capek, The Čechs (Bohemians) in America: A Study of Their National, Cultural, Political, Social, Economic and Religious Life (Boston, 1920), 137, 195-96.

19. Griffith, "Bohemian Settlement in Cedar Rapids," 165-66.

20. Dr. J. Rudiš-Jičínský, "The Bohemians in Linn County, Iowa," in Atlas of Linn County, Iowa (Davenport, 1907), 210; Irving B. Weber, Historical Stories about Iowa City, 8 vols. (Iowa City, 1976-1994), 3:195, 201; Bohumil Shimek, "The Bohemians in Johnson County," n.d., State Historical Society of Iowa, Iowa City; Cedar Rapids Centennial, 1856-1956 (Cedar Rapids, 1956). J. M. B. Letovsky founded the Slovan Americky in Iowa City in 1869 and moved his 
Over time, the Cedar Rapids Bohemian population gained a reputation for its staunch support of the Democratic Party and for its strong participation in city politics. The Cedar Rapids Standard encouraged city residents to follow the example of "our Bohemian friends" who routinely convened well-attended meetings to discuss important city matters. The Standard also denied the charge that Bohemians' votes could be bought with a round of drinks, citing the "Bohemian record for good citizenship" as proof of the absurdity of such an accusation. ${ }^{21}$

Both male and female immigrants traveled to Cedar Rapids in pursuit of economic opportunities. While men found employment as skilled and unskilled factory hands and tradesmen, women's employment options were more limited. Many young single women worked as domestic servants. Sarah Kinney, who moved to Cedar Rapids with her physician husband and four children in 1874, noted in a letter to her mother that "most servants here are Bohemians." Work as a maid was arduous. Kinney confided to her mother that she "almost [felt] wicked" letting her young Bohemian maid do all the family's washing, ironing, cooking, and cleaning for wages of three dollars per week. Some farmers' daughters worked as domestics during the slack season and returned home to work in the fields during harvest time. Others used domestic service as a way to enter the Cedar Rapids job market but moved on to employment in one of the city's factories or department stores when the opportunity arose. Like young women elsewhere, many Bohemian immigrants' daughters likely sought public employment to escape the long hours and relatively little autonomy associated with domestic service in private homes. ${ }^{22}$

printing operations to Cedar Rapids after 1872. No extant copies of the Slovan Americky exist from the period of the 1898 strike.

21. "Mr. Palda Speaks," Gazette, 8/13/1885; "Bohemians Satisfied," Standard, 12/14/1893; “An Exception," Standard, 3/19/1896.

22. Griffith, "Bohemian Settlement in Cedar Rapids," 14, 157; Sarah Kinney to Mother, 1/13/1875, 9/2/1875, Cedar Rapids Chamber of Commerce Correspondence and Clippings 1874-1957 folder, Cedar Rapids Chamber of Commerce Records, Special Collections Department, University of Iowa Libraries, Iowa City; “A Bohemian's Answer," Cedar Rapids Times, 7/12/1877. For a discussion of working women's attitudes toward domestic service, see Lara Vapnak, Breadwinners: Working Women and Economic Independence, 1865-1920 (Urbana, IL, 2009). 
For young women in Cedar Rapids, one alternative to domestic service was employment in the city's growing industrial sector. In 1898 approximately one-third of the American Cereal Company's employees were women, and of its female workers, about half were from the city's Bohemian community. ${ }^{23}$ The wrapping department was one area for which the company hired women exclusively. ${ }^{24}$ Known as "wrappers," these workers pasted packaging labels on the ends of filled boxes of oatmeal and then covered the sides with a larger wrapping. The labeling operations were conducted in a separate room in the factory where female wrappers sat on backless stools at long tables holding paste pans and brushes. Compensation was based on the piece rate system, with wrappers paid a set amount for each hundred boxes wrapped and labeled. Company management assessed fines if women accidentally tore labels or pasted boxes together or if boxes were damaged during transport from the wrapping room. During busy times, female wrappers typically worked from seven o'clock in the morning until eight or nine o'clock in the evening with a half-hour break for lunch. During the slack season, wrappers were laid off or received less pay due to the reduced volume of boxes packaged. ${ }^{25}$

DISAGREEMENTS between the wrappers and company management over wages and working conditions resulted in a walkout of approximately 100 workers on Saturday, October 22, 1898, at 2:00 in the afternoon. The women may have initiated the strike on Saturday afternoon in order to minimize disruption to their

23. The estimate of female employees at the American Cereal Company is based on an analysis of 352 company workers listed in the Gazette's 1898 city directory. Of these 352 employees, 115 (33 percent) were women; of these 115 women, 58 (50 percent) had at least one Bohemian immigrant parent. U.S. Bureau of the Census, Federal Census (1900), http:/ /0-persi.heritagequestonline.com. Again, these totals may not be precise, since some individuals employed at the mill may not have been listed in the directory.

24. The mill also hired women as clerical employees. It is possible that the company hired female workers in other departments as well, but such practices are not documented in extant records.

25. "Still Out," Gazette, 10/24/1898; “Cedar Rapids [Linn Co.], Iowa, 1895," sheet 3, Digital Sanborn Maps 1867-1970, http://sanborn.umi.com.proxy. lib.uiowa.edu/image/view $?$ state $=$ ia\&reelid=reel03\&lcid $=2597 \&$ imagename $=$ 00040\&mapname=Cedar Rapids 1895, sheet 3\&CCSI=2802n, accessed 3/14/2014. 
paychecks, hoping that after a day's reflection, company management would meet their demands by Monday. The women planned to march out together, probably anticipating that the "sight of a hundred young ladies filing out of the building and down the street [would excite] considerable comment" and center public attention on their cause. Although initially the strikers declined to present their case in detail to reporters, several unnamed representatives stated that their primary demand was higher wages and also expressed their indignation at being forced to clean up the work room after hours. ${ }^{26}$

The strikers' reticence to discuss their grievances evaporated by Monday, October 24, perhaps because management refused to discuss their demands and possibly in part because the Cedar Rapids Evening Gazette lent a sympathetic ear to their grievances. The paper's October 24 edition contained a lengthy account of a Gazette reporter's interview with an unnamed female representative of the strikers; she expressed a number of the wrappers' concerns, including their desired wage raise to 18 cents per hundred packages wrapped, an increase of almost 30 percent. Requesting such a large increase may have simply been a negotiating tactic. The interviewed striker acknowledged that "we hardly hope to secure" the requested amount, "which is small enough for the work done," but expressed the wrappers' expectation that company management would be willing to make some concessions rather than incur the expense of training replacements. ${ }^{27}$

The unnamed strikers' representative pointed out that part of the reason the wrappers wanted higher wages was that management had recently changed the wrapping procedure and the new protocol required workers to handle each package several more times than they had previously. The amount of time required to wrap each package rose significantly under the new system; the women estimated that it increased their work load by 50 percent while their wages stayed the same. The strikers' representative disputed management's contention that "with a little practice" the wrappers would be able to do as much work under the new system as they had under the old. She also dis-

26. "On a Strike," Gazette, 10/22/1898.

27. "Still Out," Gazette, 10/24/1898. 
counted company manager George McDonald's claim that wrappers typically earned between $\$ 1.00$ and $\$ 1.40$ per day. According to the interviewed female striker,

There are a few girls in the mill who might make $\$ 1.40$ a day by working from 7 in the morning until 9 at night, but Mr. McDonald forgot to say anything about the days and weeks that the mill is shut down, and the fact that the best and most industrious of us wrappers are not making much more than $\$ 2$ a week on the average. He forgot to say that whenever there is a rush he employs all the hands he can get and pushes everything as hard as he can until the order is out of the way, and then lays us all off until we are needed again. He forgot to tell anything about the system of fines which he has inaugurated and the fact that time after time we go to the mill and find that our services are not needed, frequently being compelled to wait until noon before we know whether there is going to be any work on that or the following day. He forgot to tell about charging us a cent for every wrapper we tear in handling and a number of other interesting things seem to have slipped his memory.... He did not say anything about docking us 25 cents for being off Saturday afternoon, when we are working by the hundred pieces. He did not tell the reporter that time and again they have compelled girls to work for a day or more for nothing, while they were learning how to wrap. ${ }^{28}$

This list of complaints makes clear the wrappers' resentment over not just low wages but also toward company policies that served to decrease the women's economic security as well as their paychecks. To the wrappers, management's refusal to guarantee steady work hours, the imposition of fines for normal wear and tear, and the levying of economic penalties in exchange for a few hours of free time on Saturday afternoons all represented arbi-

28. Ibid. Nationwide, the median weekly wage for women workers age 16 and older was $\$ 5.64$ in 1900, approximately half the $\$ 10.55$ median weekly wage for men. One-fourth of women workers earned less than $\$ 4.49$ per week, while only one-fourth of wage-earning women took home more than $\$ 6.86$ each week. Edith Abbott, Women in Industry: A Study in American Economic History (New York, 1910), 311-12. If, as McDonald claimed, the wrappers were earning between $\$ 1.00$ and $\$ 1.40$ per day, their weekly earnings of $\$ 6.00-8.40$ would have placed them above the median or even in the upper quartile of working women nationwide. On the other hand, if economic penalties and reduced hours during the slack season drove their average weekly wages down to $\$ 2.00$, the wrappers earned significantly less than the bottom quartile threshold of female wage earners. 
trary policies that served the company's interests at the expense of their female workers' personal security and well-being.

The strikers' representative went on to tell the reporter about other grievances related to the women's autonomy and personal dignity. She criticized McDonald for refusing to allow sick employees to leave unless they were so ill that they could no longer work, and she claimed that company management, to prevent any workers from leaving early, kept the women's hats and coats locked in the dressing room until the noon break and quitting time. The strikers also chafed at one of management's new regulations, which required workers to telephone or telegraph ("Just imagine one of us paying 10 cents for a messenger!") on days when they could not come to work. Company managers, the women complained, refused to extend the same courtesy to their workers. Instead of informing employees in advance of a shutdown in operations, management required employees to report to the mills each day to find out if their services would be needed. On slow days, managers expected the women to wait, seated silently at their work tables, until boxes became available for wrapping. The wrappers resented the limited time off available for holidays or other special events; the strikers' representative noted the women's disappointment at being required to work on Labor Day. ${ }^{29}$

The strikers also decried the poor working conditions in the wrapping room. They took exception to being forced to furnish their own ice water and water cooler but particularly resented paying for replacement brushes and paste pans when those provided by the company wore out after normal use. Those workers

29. "Still Out," Gazette, 10/24/1898. It is not clear from the Gazette's report whether the stringent company controls over workers' ability to leave the factory before the end of the work day applied to male workers as well, but such close monitoring was likely limited to female employees. Employers often exercised greater paternalism in their regulation of female workers. See, for example, Tentler, Wage-Earning Women, 28; Kessler-Harris, Out to Work, 162; Patricia A. Cooper, Once a Cigar Maker: Men, Women, and Work Culture in American Cigar Factories, 1900-1919 (Urbana, IL, 1987); and Norwood, Labor's Flaming Youth, 3639. Company owners and managers at times instituted stricter controls of women laborers in order to demonstrate the respectability of their workplaces and to reassure parents of young women workers that company regulations would substitute for familial controls in the public world of waged labor. However, such supervision placed greater limitations on women employees' freedom and personal autonomy. 
whose pans rusted through sooner than "Mr. McDonald thought they ought to" plugged the old ones with rags rather than ask for new ones. In addition, the strikers resented being forced to stay after hours to clean up the wrapping room. McDonald docked the pay of those who refused to work overtime scrubbing their work spaces, additional labor that cut into the women's already limited free time. The wrappers also complained of a new regulation that required the women to carry off the wrapped boxes in large trays weighing 20 pounds each, a task for which management had formerly employed young men. While clearly a costsaving measure for the company, McDonald justified the change with the disingenuous argument that "boys and girls" should not work together. ${ }^{30}$

The cereal workers' grievances reflected common concerns expressed by other women workers in the late nineteenth and early twentieth centuries. Proposed wage cuts provided the impetus for many female-led strikes. ${ }^{31}$ During this period, women on average earned half what men did. ${ }^{32}$ This wage differential was justified in part by the assumption that women worked out of inclination, to earn money for luxuries, rather than out of necessity. However, many women, including the unmarried and those who had been widowed or abandoned or whose husbands were unable or unwilling to earn a living wage, entered the waged marketplace to support themselves and often other family members as well. In those households, a working woman's wages meant the difference between survival and starvation.

30. "Still Out," Gazette, 10/24/1898. Factory employers often required workers to purchase supplies needed in the course of their employment. Garment workers, for example, often had to buy their own needles, thread, and occasionally even sewing machines. Workers resented these charges against their wages and at times included the elimination of such deductions in strike demands. See Tentler, Wage-Earning Women, 23-24; Susan Levine, " ‘Honor Each Noble Maid': Women Workers and the Yonkers Carpet Weavers' Strike of 1885," New York History 62 (1981), 153-76; Barbara Speas Havira, "Dwindling into Failure: The International Ladies' Garment Workers' Union Strike in Kalamazoo, 1912," Michigan Academician 20 (1988), 397-415; Kornacki, “Revealing Division," 367-68.

31. Philip S. Foner, Women and the American Labor Movement: From Colonial Times to the Eve of World War I (New York, 1979), 236-37.

32. Ruth Milkman, "Organizing the Sexual Division of Labor: Historical Perspectives on 'Women's Work' and the American Labor Movement," Socialist Review 49 (Jan.-Feb. 1980), 116. 
Wages represented an important issue for women workers nationwide, but female employees also expressed concerns about issues of personal dignity. Like the wrappers in Cedar Rapids, women workers at a Pittsburgh pickle plant resented being forced to spend four hours each Saturday on their hands and knees, scrubbing the tables and floor in their work space. ${ }^{33}$ In the 1909-1910 New York shirtwaist strike, striking women's grievances included unsanitary working conditions, sexual harassment, and a lack of dressing rooms in which workers could hang their coats and hats. ${ }^{34}$ Female workers demanded reasonable wages and the recognition of their human dignity.

The Cedar Rapids cereal workers' demands, like those of female strikers elsewhere, highlighted two key areas of concern. The first grievances listed dealt with wage levels and economic insecurity. By claiming higher wages and more regular hours, the strikers positioned themselves as legitimate wage earners who deserved "living wages." 35 At a time when society viewed women workers as marginal industrial employees and temporary members of the workforce, the striking wrappers demanded recognition as serious, industrious laborers who deserved fair compensation from their employer. In addition to wage concerns, the strikers also expressed the desire to be treated as responsible adults. Company policies that implied that the wrappers might sneak away from their posts or that they would negligently damage company property relegated the women to the status of children in need of company management's paternalistic guidance and discipline. By calling for an end to such regulations, the strikers implicitly demanded respect as conscientious, mature human beings.

In addition to reporting on the strikers' concerns, the Gazette also reported a conversation with an unnamed former male employee of the cereal company who shared gendered grievances at odds with those articulated by the female wrappers. Although he acknowledged his support for the striking women, the male respondent largely ignored their demands in his assessment of

33. Foner, Women and the American Labor Movement, 260.

34. Enstad, Ladies of Labor, 140-41.

35. "They Take Action," Gazette, 10/27/1898. 
the company. He did argue that the mill should either pay higher wages or guarantee employees steadier employment throughout the year, but then he turned his attention to demands for better treatment of long-term, aged employees, denounced the employment of women in jobs formerly reserved for men, and decried the company's policy of deducting accident insurance premiums from employees' paychecks. ${ }^{36}$ Comparing these concerns to those expressed by the striking women demonstrates that male and female workers experienced the workplace in gendered ways. Young female workers generally viewed their stint in the paid workforce as temporary and so did not feel threatened by company mistreatment of long-term employees. In addition, women workers most likely would not have participated in companysponsored benefits such as insurance plans. The target market for accident insurance, which in the event of accidental death or injury indemnified workers and their families for lost or diminished wages, was the male head of household. ${ }^{37}$ Even if deemed eligible for such coverage, women workers would likely have been unwilling or unable to have insurance premiums deducted from their already low wages. As women, the strikers faced gender-specific struggles in the workplace, and their demands expressed concerns that varied from those of male workers.

In the Gazette's report of the strikers' demands, the strikers' representative took advantage of the opportunity offered by the sympathetic Gazette reporter to publicly state the strikers' case and gain community support for the strike. The unnamed interviewed striker was careful to lay the blame for the dispute at the feet of manager George McDonald, who had recently joined the company, and to point out that the strikers had no complaint against their direct supervisor, foreman Thomas Bithray. The strikers expressed particularly harsh condemnation of McDonald, claiming that he "has tried to make slaves of us" by asking the women to work on Sundays and asserting that "no man under [McDonald] dare say that his soul is his own if he wants to hold

36. "Expert Opinion," Gazette, 10/25/1898.

37. George E. McNeill, A Study of Accidents and Accident Insurance (Boston, 1900); Robert Whaples and David Buffum, "Fraternalism, Paternalism, the Family, and the Market: Insurance a Century Ago," Social Sciences History 15 (1991), 97-122. 
his job." As a new addition to the company, McDonald was not yet an established member of the community, unlike Bithray, who had been employed as foreman for at least three years. ${ }^{38}$ The women may have hoped to gain more public sympathy by focusing their complaints on a relative stranger and his new and allegedly unreasonable regulations. By carefully explaining the reasons behind their demands and positioning those demands as a rational response to the unfair policies instituted by a new manager unfamiliar with company and community mores, the women hoped to elicit support from the citizens of Cedar Rapids.

IN THEIR APPEAL for public sympathy, the strikers benefited from the Gazette's supportive coverage of the strikers' demands, a stance that stemmed at least in part from editor F. W. Faulkes's opposition to the tax exemptions granted to the American Cereal Company. Faulkes, a one-time Republican, had abandoned the party in 1893 after disagreeing with local Republican leaders; thereafter Faulkes adopted an independent, often pro-Democratic, stance. ${ }^{39}$ Faulkes did not initially oppose the Republican-led city government's approval of the company's 1895 petition for tax exemption, but in the following three years the Gazette's coverage became increasingly negative. ${ }^{40}$

In early 1896 Faulkes editorialized against the city's ceding to "the oat meal trust" a "free gift of $\$ 7,000$, " the granting of which required an increase in taxes levied against other businesses and individual property owners in the city. ${ }^{41}$ Two years later, the $G a$ zette ran a series of articles, complete with tables of statistics com-

38. Thornton, History of the Quaker Oats Company, 212; "Still Out," Gazette, 10/24/ 1898; "Iowa State Census 1895," https://familysearch.org (accessed February 2014). Bithray seems to have developed a good working relationship with the women in his department. The Gazette reported that on Christmas Eve, 1895, the "young ladies of the packing department of the oatmeal mills surprised their foreman, Mr. Bithray, with a writing desk, etc." See "The City in Brief," Gazette, 12/26/1895.

39. Brewer, History of Linn County, 116.

40. "Taxes Are Rebated," Gazette, 5/22/1895; "Something about City Matters!” Gazette, 2/29/1896; "Large Interests," Gazette, 1/24/1898; "American Cereal Company," Gazette, 2/4/1898; "Large Interests," Gazette, 2/12/1898; "Home Owners," Gazette, 2/26/1898.

41. “Something about City Matters!” Gazette, 2/29/1896. 


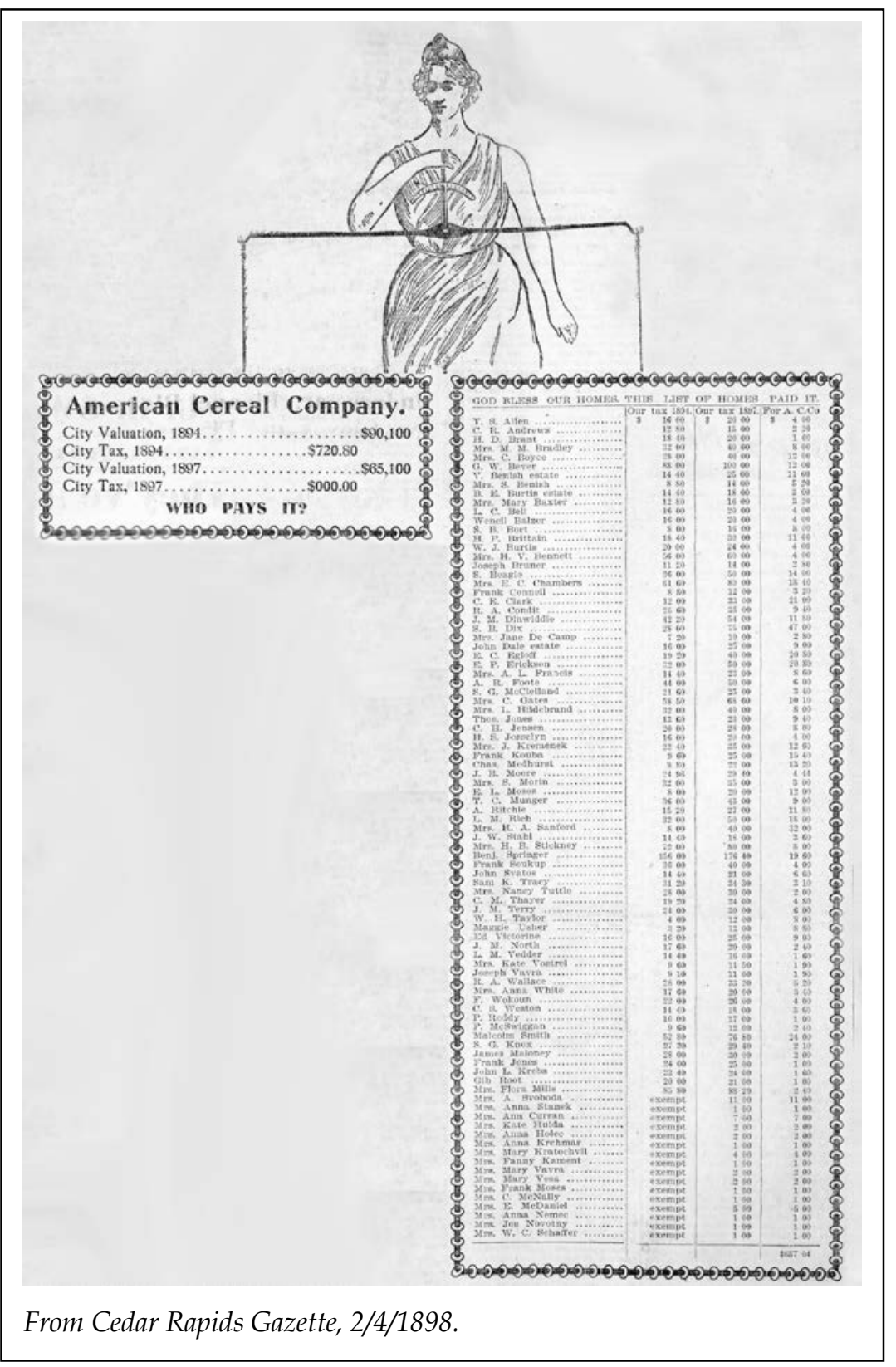


paring county and city valuations and taxes paid by some of the city's largest corporations. Although the articles addressed city tax policy generally, prominently situated in each report was an image of Lady Justice holding scales balancing on one side the taxes paid by the American Cereal Company prior to 1895 and on the other increased taxes levied against businesses and home owners to make up the lost revenue resulting from the cereal company's post-1895 tax exemptions. ${ }^{42}$ In one such article, included under the headline "Oat Meal Mill Exemptions" was the phrase "God help the rich, the poor can beg" followed by several blank lines upon which, Faulkes explained, "readers of The Gazette can write their sentiments on this matter." 43 This appeal to his readership indicates that Faulkes perceived, or hoped to generate, significant public opposition to the cereal company's tax exempt status.

During the strike, Faulkes drew connections between the striking women's grievances and the city's tax policy. He argued that one reason the city council decided to exempt the company from taxation was company managers' promise to provide good jobs and steady employment for the city's citizens. Instead, Faulkes asserted, the company paid "starvation wages" to its female employees, wages too low to cover the necessities of life. In addition, working-class families' net incomes had suffered since "the people who own modest homes, people who may have daughters among the strikers," faced stiffer tax levies to make up for city revenue lost through the cereal company's tax exemptions. ${ }^{44}$ American Cereal Company workers' finances took a double hit when the company paid low wages and the city taxed them at a higher rate to recover lost tax revenue.

Faulkes's support of the strikers did not stem entirely from his disagreement with Republican Party politics and opposition to American Cereal Company's tax exempt status but also from his support for young women laborers, expressed in earlier editions of the Gazette. In response to a deprecatory reference to waitresses as "biscuit shooters" made by a young man in a local restaurant, Faulkes defended "hard-working girls, earning an

42. Gazette, 2/4/1898, 2/5/1898, 2/7/1898, 2/12/1898.

43. "Oat Meal Mill Exemptions," Gazette, 2/4/1898.

44. "The Strike and Other Things," Gazette, 10/26/1898. 
honest living, perhaps assisting in the support of their families" and compared their "ennobling" labor to the indolence of those "who live upon the cake and pie furnished by their fathers." 45 During the strike, Faulkes noted that most of the "girls" employed by the cereal company were young women, many of whom had been with the company for many years. A number of the women, Faulkes pointed out, worked out of necessity, to support themselves and perhaps other dependents, not so they could "indulge in luxuries." 46 Women, Faulkes argued, had the same right as men to a living wage. ${ }^{47}$

Support for female wage equality was rare in an era when many working men and their allies viewed women's employment as a serious threat to men's ability to earn a "family wage," a level of earnings that would allow the male head of household to serve as sole breadwinner. According to Carroll Wright, the U.S. Commissioner of Labor in 1888, women who worked for "small pay, needing money only for dress or pleasure," helped to lower the wages of all workers. ${ }^{48}$ Faulkes recognized that many young women pursued waged employment out of need; his political leanings and respect for women's labor ensured a public platform for the striking women's grievances. ${ }^{49}$

45. "Only a Biscuit Shooter," Gazette, 8/13/1885.

46. "The Strike and Other Things," Gazette, 10/26/1898.

47. Faulkes's mother, Ann, provided a powerful example of the necessity of women's labor in the face of family tragedy. In 1870, 15-year-old Faulkes lived with his English immigrant parents in Dane County, Wisconsin: father, James, listed in federal census records as a "farmer," and his mother, Ann, recorded by the census enumerator as "keeping house." Ten years later, only Ann appeared in federal census records, as a widow and now identified with the occupation of "farmer." With the death of James Faulkes, Ann took on the responsibility of farm management, assisted by a hired farm hand and a servant. His mother's experiences likely influenced Faulkes's stance on working women. U.S. Bureau of the Census, Federal Census (1870, 1880), http:/ /0-persi.heritagequestonline.com.

48. Kessler-Harris, Out to Work, 100.

49. The other major daily Cedar Rapids newspaper, the Cedar Rapids Daily Republican, also expressed support for the striking women but provided less detailed coverage of their grievances and actions. The Republican's editor called the women's demands both "reasonable" and "right" but called for arbitration of the workers' grievances rather than a "hurtful strike." See "The Oatmeal Mill Strike," Cedar Rapids Daily Republican (hereafter cited as Republican), 10/27/1898; "The Strike Ended," Republican, 10/28/1898. 
The Gazette's favorable coverage continued on October 25, when it characterized the women's ransacking of the wrapping room as a "little harmless fun." After the strikers had met with McDonald and been told once again that the company would not meet their demands, the women proceeded to their former workroom where they accosted the "children" and "married women" the company had employed to replace the strikers. The women used their former work area as a space in which to demonstrate their solidarity and commitment to their cause. In addition to overturning paste pans and opening packages of oatmeal, the strikers subjected some of the replacement workers to "a tongue lashing they will not forget in a day." The strikers' verbal harangue encouraged some strikebreakers to leave their work tables and join the strikers' ranks. ${ }^{50}$

THE WOMEN'S DISRUPTION of wrapping operations also got McDonald's attention. Arriving at the wrapping room, he sought to quell the disturbance by explaining that his superiors refused to consider the women's demand for higher wages, but he did offer to abolish the system of fining employees for torn labels and to reduce their workload by rescinding the order that wrappers clean their work spaces at the end of the day. The strikers refused McDonald's offer and pressed for a wage increase. They also rejected his suggestion that a forewoman from the Akron plant travel to Cedar Rapids to teach the women to wrap packages more quickly, fearing that such a move would reflect negatively on their local foreman's training and managerial skills. 51

The young female strikers refused to be intimidated by company management and claimed the right to make their case in the very space where they felt their labor had been unfairly appropriated. The women rejected McDonald's offer to settle the strike on terms that did not address their key demands. In addition, as the Gazette reported, the strikers "asked the manager some very pertinent questions," including why he could always get an immediate answer from his superiors on any question not related

50. “Could Not Agree," Gazette, 10/25/1898.

51. Ibid. 
to a wage increase "while it takes days and even weeks to get an answer regarding their demands." 52 The striking women claimed the right to negotiate as equals with management and refused to surrender their demands despite management's opposition.

The experienced wrappers also rebuffed McDonald's paternalistic efforts to "teach" them to be better and more efficient workers. Throughout the strike, female strikers positioned themselves as skilled workers and portrayed McDonald as an inexperienced manager who did not understand their craft. That the women took pride in their work and their identification as wrappers is evidenced by the comments of the unnamed strikers' representative in the Gazette's initial account of the strikers' grievances. The very first concern addressed by the unnamed striker was not wages or working conditions but the strikers' identity as workers: "We want first to correct the impression that the 135 girls who walked out Saturday afternoon were packers. We were 'wrappers.'" 53 The experienced female workers contested McDonald's new wrapping procedure because it was inefficient and unnecessarily time-consuming. All accounts of company efforts to replace the strikers noted the strikebreakers' inexperience and inability to get the job done, which forced the mill to incur the extra expense of sending train-carloads of packages to Chicago for wrapping. The women took pride in their work and resented McDonald's heavy-handed and ill-conceived attempts to arbitrarily alter their work patterns and his disregard for the value of their skill and expertise. The wrappers' valuation of their work as a skilled craft may have helped strengthen their resolve to strike and their commitment to achieving their goals. ${ }^{54}$

After the striking women ransacked the wrapping room, company management refused them further access, forcing the women to switch tactics. On the evening of October 25 and the

52. Ibid.

53. "Still Out," Gazette, 10/24/1898.

54. Dorothy Sue Cobble found a similar assertion of skilled craftswomanship among waitresses. Like the wrappers in Cedar Rapids, waitresses acquired most of their training and experience on the job, and the larger society viewed the work of both groups as unskilled. Waitresses' self-evaluation as skilled craftswomen, Cobble argues, helped provide a strong basis for union organization among waitresses. See Cobble, Dishing It Out. 
morning of October 26, groups of strikers congregated outside the mill and remonstrated with the workers who had been hired to take their place. The Gazette reported that two-thirds of the 60 strikebreakers were girls under the age of 14 . In the pages of the Gazette, the striking women invited mothers and fathers of the young strikebreakers to attend the strikers' meeting that evening. The women hoped to convince the parents of the reasonableness of the strikers' demands and to persuade them to keep their children out of the mill. The strikers had already contacted the county attorney's office regarding the legality of employing such young workers, but at that time, the state's child labor laws applied only to work in coal mines, and no compulsory education statute existed to force children out of the mill and into the classroom. ${ }^{55}$ Creative and resourceful, the striking women used a variety of tactics to keep strikebreakers out of the wrapping room and the cereal company on the defensive.

The war of words between the strikers and McDonald continued, and, for the first time, questions of ethnic distinctions entered the rhetorical battle. McDonald claimed that the strike would not interfere with the mill's business, purportedly stating that he could hire as many replacement workers as needed since "the Bohemians are easy" and "will not stand out with the others." ${ }^{6}$ As a newcomer to the city, McDonald may have expressed these sentiments without realizing the strength of the Bohemian community. The strikers used McDonald's comments to intensify support for their cause; the Gazette reported that the strikers "have not only taken exception to the slur upon them but assert that ... they will stay out [until] . . their demands are acceded to." 57

In its defense of the striking women's ethnic reputations, the Gazette noted that "there are a number of representatives of eminently respectable Bohemian families" among them. That observation was validated when the names of the strike leaders became public the next day. Until October 27, none of the strikers had been identified by name in newspaper reports. On that day,

55. "Strike Still On," Gazette, 10/26/1898; "The Strike Spreads," Republican, 10/27/1898; Frederick Emory Haynes, "Child Labor Legislation in Iowa," in Applied History, ed. Benjamin F. Shambaugh, 6 vols. (Iowa City, 1912-1930), 2:591. 56. "Strike Still On," Gazette, 10/26/1898.

57. Ibid. 
the Gazette reported on the strikers' mass meeting held the previous evening, which had been called to order by wrapper Myrtle Gallagher. The room in which the strikers met was "filled ... to suffocation" with striking women, "many of the male employees in other departments and a large number of friends and sympathizers." Gallagher's audience responded jubilantly when she announced that two of McDonald's superiors from the Chicago office would arrive in Cedar Rapids the following day. The strikers hoped to carry their grievances over McDonald's head and gain satisfaction from his bosses. ${ }^{58}$

They did not, however, intend to simply rely on company management's good will. Striker Katie Molloy offered a motion to appoint a committee of five strikers to meet with the city council to request that city leaders rescind the American Cereal Company's tax exempt status, a move designed to exert financial pressure on the company. After the assembled strikers unanimously adopted the proposed motion, Gallagher appointed to that committee Lillie Molloy, Libbie Letovsky, Addie Searles, Maggie Carroll, and Mary Poduska. ${ }^{59}$

THE YOUNG WOMEN who emerged as strike leaders were a diverse group. ${ }^{60}$ All were single women in their teens or twenties; the youngest was 16-year-old Myrtle Gallagher and the oldest was Lillie Molloy, at age 28. ${ }^{61}$ Lillie Molloy had been employed

58. Ibid.; “They Take Action,” Gazette, 10/27/1898.

59. "They Take Action," Gazette, 10/27/1898.

60 . Of the women named in the Gazette report only one, Katie Molloy, could not be traced through state or federal census records or city directories. It is possible that it was Lillie Molloy, misidentified as Katie in the Gazette story, who offered the motion to meet with city leaders to contest the company's tax-exempt status.

61. Federal Census (1900); “Iowa State Census, 1895," https://familysearch .org/search/collection/1803957; "Iowa State Census, 1885," https://familysearch.org/search/collection/1803643. In federal and state census records and city directories, Lillie Molloy was alternately listed as Lillie, Lill, Lizzie, and Elizabeth. At age 16, Gallagher was the youngest of the strike leaders and also their chairwoman. During the late nineteenth and early twentieth centuries, it was not unusual for young women to play leadership roles in the labor movement. Elizabeth Gurley Flynn, who later became a prominent organizer for the Industrial Workers of the World (IWW), gave her first public speech on socialism at age 16 and began a nationwide speaking tour for the IWW one year later. Fannia Cohn became an active member of the Socialist Revolutionary Party in Belarus at age 16 before immigrating to the United States and working as a labor 
at the American Cereal Company for at least eight years; the others were more recent hires, having been with the company for one to three years. ${ }^{62}$ Addie Searles had worked as a domestic and Maggie Carroll had been employed at a cracker factory before being hired at the oatmeal mill; there is no record that the other women had worked elsewhere before joining the cereal company. ${ }^{63}$

Of those women whose living arrangements are documented, two lived in households with two parents and siblings, two lived with widowed mothers and siblings, one lived with her father and brother, and one lived alone. ${ }^{64}$ Among these six women, at least three appear to have made significant, if not the sole, contribution to their families' income. In addition, three of the six women lived in households in which other family members were employed at the American Cereal Company. ${ }^{65}$ Family members familiar with the companies' employment practices may have tended to support the striking women's cause. On the other hand, fathers and brothers employed at the mill may have worried that a striking family member's militant stand against the company would put their own job at risk.

The female strike leaders also varied in their ethnic background. Addie Searles was the only one in the group who had been born in the United States to U.S.-born parents. ${ }^{66}$ The other strike leaders had ties to immigrant groups in the city. Maggie Carroll had been born in Ireland and emigrated to the United States with her family when she was eight years old. ${ }^{67}$ Both Myrtle

organizer for the International Ladies Garment Workers Union. See Elizabeth Gurley Flynn, The Rebel Girl: An Autobiography, My First Life (1906-1926), rev. ed. (New York, 1973); Annelise Orleck, Common Sense and a Little Fire: Women and Working-Class Politics in the United States, 1900-1965 (Chapel Hill, NC, 1995).

62. Cedar Rapids City Directories (1880-1888), 1888-01-01, Digital Archives of the Marion Public Library, http:/ / mpl.newspaperarchive.com/1880-1889; Cedar Rapids City Directories (1890-1898), 1890-01-01, 1892-01-01, 1893-01-01, 1895-01-01, 1896-12-01, 1898-05-01, Digital Archives of the Marion Public Library, http:/ / mpl.newspaperarchive.com/1890-1899.

63. Ibid.

64. Ibid.; Cedar Rapids City Directories (1900-1909), 1900-01-01, Digital Archives of the Marion Public Library, http:/ / mpl.newspaperarchive.com/1900-1909.

65. Cedar Rapids City Directories (1890-1898), 1896-12-01, 1898-05-01.

66. “Iowa State Census, 1895”; Federal Census (1900).

67. Ibid. 
Gallagher and Lillie Molloy were born in the United States to Irish immigrant parents. ${ }^{68}$ Libbie Letovsky and Mary Poduska belonged to the city's Bohemian community; both were Iowaborn offspring of Bohemian immigrant parents. ${ }^{69}$

Both occupational and social ties bound together the diverse group of female strike leaders. Myrtle Gallagher, Maggie Carroll, and Lillie Molloy shared a common circle of friends. Prior to the strike, all three women attended parties with mutual acquaintances. ${ }^{70} \mathrm{~A}$ number of the other attendees at those social gatherings also worked at the American Cereal Company. Friendships formed inside the factory and out helped bind together the striking wrappers.

Altogether, the larger group of striking women workers exhibited some characteristics at odds with those of the strike leaders. The 1898 Cedar Rapids city directory listed 111 nonclerical and nonsupervisory female employees of the American Cereal Company, a number very close to the reported 100 striking wrappers. ${ }^{71}$ Although it is likely that the company's roster of female employees changed somewhat between May 1898, when the directory was printed, and the October strike, an analysis of the characteristics of the 111 identified women workers at the company represents a relatively accurate group portrait of the striking wrappers. ${ }^{72}$ The average age of this group of female employees was slightly less than 18 years, with three-quarters under the

\section{Ibid.}

69. Ibid. Libbie Letovsky was the daughter of Bohumil Letovsky, one of the Letovsky brothers who published the Bohemian-language newspaper Slovan Americky in Cedar Rapids. Libbie's uncle J. M. B. Letovsky was elected to the state legislature in 1890. See ibid.; Rudiš-Jičínský, "The Bohemians in Linn County, Iowa," 210; Shimek, "The Bohemians in Johnson County."

70. "The City in Brief," Gazette, 5/12/1892; "A Surprise Party," Gazette, 10/11/ 1897; "A Dancing Party," Gazette, 10/18/1897.

71. Of the 111 women listed in the city directory, only six could not be traced through state or federal census records.

72. The identity of the vast majority of the striking wrappers cannot be determined since newspaper reports identified only the strike leaders by name. Although accounts of the strike emphasized the women's unity, there were nevertheless cracks in the strikers' solidarity. On October 26, the Gazette reported that four of the strikers had gone back to work in order to teach strikebreakers how to wrap oatmeal packages, demonstrating that at least some of the cereal company's female employees did not actively support the wrappers' strike. 
age of 20. The directory identified only one woman with the title "Mrs.," indicating that virtually all of the company's female employees were unmarried. Although women from the city's Irish immigrant community made up half of the strike leadership, that group represented only 9 percent of the company's total female workforce. Seventy-four percent of the female employees resided in two-parent households, compared with only 33 percent of the strike leaders. The women who emerged as strike leaders were much more likely to live in households where their earnings represented a more significant share of total income and may have taken on leadership roles in part out of a greater sense of responsibility for family support. ${ }^{73}$

For those female cereal company employees who lived in male-headed households, their fathers' occupations may shed some light on the wrappers' familiarity with the strategies of organized labor. ${ }^{74}$ Half of the company's women workers had fathers employed either as craftsmen or by one of the city's railways. Those two groups of workers had historically high levels of union membership. ${ }^{75}$ By the turn of the century, union locals had been established in Cedar Rapids for carpenters, locomotive firemen, railway conductors, switchmen, machinists, and stone masons, all occupational groups in which female cereal workers' fathers were employed. ${ }^{76}$ The women wrappers undoubtedly heard discussions of union goals and tactics in their homes and at community events, and that familiarity with the principles of organized labor likely influenced the strategies they employed during the strike.

73. Cedar Rapids City Directories (1890-1898), 1898-05-01; “Iowa State Census, 1895"; Federal Census (1900).

74. Of those female cereal company employees who could be identified in census records, only two lived in households in which their mothers were identified as being employed outside the home.

75. For a discussion of railroad workers' involvement with organized labor, see Shelton Stromquist, A Generation of Boomers: The Pattern of Railroad Labor Conflict in Nineteenth-Century America (Urbana, IL, 1987).

76. "Great Growth of Labor Union Locals," Republican, 1/7/1903. I could find no evidence that directly tied parents or other family members of the strike leaders to organized labor. In addition, although the Gazette reported that the "strikers have won the sympathy of all who have heard the story of their demands" ("Still Out," Gazette, 10/24/1898), I could find no evidence that any labor unions in Cedar Rapids publicly expressed support for the wrappers' strike. 
AT THE STRIKERS' MEETING on October 26, the committee of five women appointed by chairwoman Myrtle Gallagher was charged with presenting to the mayor and city council the following petition:

In view of the recent action of the management of the local mill of the American Cereal company, in refusing to grant our just demands, we, the undersigned representatives ... of the striking employes of that company, and in pursuance to a resolution adopted at a mass meeting ... hereby petition your honorable body to rescind the resolution by which the property of said company was exempted from all taxation for a period of ten years. ${ }^{77}$

The Gazette reported that the motion to adopt "was passed with rousing cheers," and the committee of five immediately made arrangements to meet with the mayor, setting an appointment by telephone to confer with him in his offices at 8:30 the following morning. The meeting ended with several strikers urging the women to "hold together to the last." After the strikers decided to meet outside the mill at 7:00 the next morning to discourage strikebreakers, Gallagher urged her fellow wrappers to refrain from violence or any public demonstrations that might serve to undermine community sympathy. 78

Petitioning the city council to rescind the American Cereal Company's tax-exempt status was a bold and creative strategy on the part of the strikers. The women drew on public antipathy to city tax policy to emphasize the size and economic strength of the mill in opposition to their own position as underpaid wage earners and members of individual tax-paying households. They hoped to strengthen public support for their cause through peaceful protest that highlighted Cedar Rapids citizens' vulnerability to the political clout of such a large corporation. In addition, the strikers hoped to put significant financial pressure on the company by threatening its tax-favored status. In 1894, before the city council had granted its petition for tax exemption, the American Cereal Company had paid $\$ 720.80$ in city taxes. ${ }^{79}$ Any improvements made by the company during the succeeding four years would have further

77. “They Take Action,” Gazette, 10/27/1898.

78. Ibid.

79. “American Cereal Company," Gazette, 2/7/1898. 
increased the mill's assessed value and associated annual property taxes. The strikers' threat was not an empty one. According to the Cedar Rapids Daily Republican, the council's 1895 resolution to exempt the company from taxation was illegal; any taxpayer in the city could file a petition requesting assessment of the American Cereal Company's property for taxation. ${ }^{80}$

The young women strikers chose to pressure the company through city political offices even though, as women, they were not eligible to vote in city elections. They claimed their rights as citizens to bring their grievances before elected officials and expected the mayor and city council members to be responsive to their concerns. Denied the right to directly influence city politics through the ballot box despite their status as wage earners and taxpayers, they nevertheless attempted to shape city tax policy through petitions and public sentiment. ${ }^{81}$

On the afternoon of October 28, the women got to state their case in a meeting with three officials from the mill's Chicago headquarters: J. A. Arbogast, Otis Hower, and Ed Mower. ${ }^{82}$ Prior to the meeting, Arbogast boasted to a Gazette reporter that he "would make the girls laugh at themselves" and convince them to accept the company's terms. Arbogast opened the conference with the strikers' committee by telling the women they were foolish and assuring them that "only ignorant and illiterate people like Bohemians, Poles, Finns, Welsh, [and] Italians ... ever strike any more." Whether Arbogast understood the ethnic composition of the committee is not known, but his remarks failed to impress the strikers. He then offered to pay the women wrappers $\$ 1.00$ per day for 12 days, after which time they were to return to work at the old wage scale. That proposal was intended to provide the women with a guaranteed daily wage until they learned the new wrapping procedure. As the Gazette reported, however, the strikers' representa-

80. “The Strike Spreads," Republican, 10/27/1898.

81. Women in Iowa had very limited voting rights in 1898. In 1894 the state's General Assembly granted women the privilege of voting only in those elections that involved the issuing of bonds, borrowing money, or increasing the tax levy. Not until the ratification of the Nineteenth Amendment in 1920 did women in Iowa gain full voting rights. See Louise R. Noun, Strong-Minded Women: The Emergence of the Woman-Suffrage Movement in Iowa (Ames, 1969), 231, 260-61.

82. “The Strike Ended," Republican, 10/28/1898. 
tives "flatly refused" the company's offer and reiterated their commitment to pursue revision of the company's tax status. ${ }^{83}$

After the afternoon's impasse, company officials met with the strikers' committee again that evening. Arbogast and Mower downplayed their concern over losing tax-exempt status, arguing that the company could easily afford to pay $\$ 720$ in annual city taxes. The strikers' representatives countered that the two men "must think [the wrappers] had a poor idea of values" if they believed they could convince the strikers that " $\$ 720$ was all that they were likely to be compelled to pay" given the improvements made during the past three years. ${ }^{84}$ After that rejoinder, Arbogast and Mower left the room to confer. When they returned, they agreed to the following concessions: a 14 percent raise for the new wrapping style; ending the requirement that the women clean the wrapping room after hours; abolition of fines for accidentally tearing wrappers or gluing packages together; new and larger tables in the wrapping room; and the installation of a conveyor belt system so that the women would no longer have to carry cereal packages to and from their work tables. ${ }^{85}$ The settlement represented a favorable resolution of all the striking wrappers' primary grievances.

Jubilant at their success, the women nevertheless took precautions to solidify their victory. They immediately drafted a letter

83. "Girls Have Won Strike," Gazette, 10/28/1898. In addition to the ethnic groups noted, Arbogast also used a racial epithet to include African Americans among the "ignorant and illiterate people" who continued to resort to strikes to settle labor disputes. By lumping together "undesirable" immigrant groups with African Americans, Arbogast suggested an ambiguous racial status for members of the city's Bohemian community.

84. Ibid. Company officials may have been concerned that a challenge to the plant's tax-exempt status might invalidate the original agreement, leading to an assessment of back taxes plus interest. The total value of the company's ten-year tax exemption was equal to $\$ 7,208$, assuming no increase in assessment due to hikes in property values, a sum that would be equal to approximately $\$ 200,000$ in 2014. Company management may have also been anxious to avoid any adverse financial impact, no matter how small. During the summer and fall of 1898, a proxy battle was brewing over control of the American Cereal Company's board of directors, and company officials may have been concerned about the effect that any financial loss could have on stock prices. For a discussion of the 1898 proxy battle, see Marquette, Brands, Trademarks, and Good Will, 73-77.

85. “Girls Have Won Strike,” Gazette, 10/28/1898. 
to company management at the Chicago headquarters. The communiqué opened with a statement of "utmost confidence in the integrity and fairness of ... foreman Mr. Thomas Bithray" and requested that he be retained as their supervisor. Perhaps anticipating backlash from McDonald, the women proactively praised Bithray to company management, staving off any anticipated attempt by McDonald to blame the foreman for the strike. The wrappers had a good working relationship with Bithray and wanted him to remain as a potential future ally and buffer between the women and McDonald. After their praise of Bithray, the women wrote, "We desire to express our most sincere appreciation of the concessions which the representatives of the company have made to us today with the hope that nothing may arise in the future to mar our relations. We would assure the management that we will at all times work for the best interests of the company and thereby best serve our own interests." Here, the women extended an olive branch of conciliation after a period of contentious negotiation and sought to reestablish a sense of harmony with their employer. But they also put into writing the fact that company officials had conceded to their demands. Without listing the details, they nevertheless documented the existence of those concessions. To further cement their gains, the women sent a copy of the letter to McDonald, along with a note "assur[ing] him of their esteem and express[ing] the hope that in the future there would be no further difficulties." 86

LOCAL NEWSPAPERS hailed the end of the strike as a victory for the women workers. According to the Gazette, the wrappers secured "as much as they asked and more than they expected." The paper credited their triumph to "the good judgment, strong will and excellent tact of the young ladies ... to whom the management of their affairs was entrusted." Similarly, the Republican praised the women for their "sensible" conduct and opined that "to the women themselves is due the welcome settlement - they were reasonable in their demands as well as right." 87

86. Ibid.

87. Ibid; “The Strike Ended," Republican, 10/28/1898. 
Despite these accolades for the strikers and their victory, the strike's outcome left several issues unresolved. The cereal company's capitulation to the women's demands left open the question of its tax-exempt status. In May 1895 the city had exempted the American Cereal Company from taxation for a period of ten years. However, on March 8, 1905, before that term expired, the company suffered a devastating loss when its entire Cedar Rapids plant burned to the ground. Following that catastrophe, business leaders led the way in calling for a seven-year extension of the company's tax-favored status to encourage rebuilding of the mill in the city. ${ }^{88}$

Nor did the ending of the strike resolve the wrappers' vulnerability, as non-unionized workers, to future wage reductions or management's arbitrary introduction of additional duties or penalties. At least one of the strike leaders worked to change that situation. In 1902, four years after the wrappers' successful strike, Maggie Carroll, a member of the strikers' negotiating committee, helped organize Local 20 of the International Union of Flour and Cereal Mill Employees. ${ }^{89}$ Local 20 was established as an organization for female workers at American Cereal Company; other locals were set up for male employees of the mill. The union proved to be popular among the wrappers. In 1903, 125 members of Local 20 marched in the city's Labor Day parade and won first prize for the "best appearing union," with three rose-festooned floats. ${ }^{90}$ Local 20 also sponsored a women's drill team, established in 1904 and composed of some of the youngest members of the union. ${ }^{91}$ In their handmade, colorful uniforms, the drill team performed at the city's 1904 Labor Day celebration and other union events, executing "fancy evolutions" and carrying lettered placards with which they spelled out "Demand the Label." 92

88. "Board Will Hold Special Session," Gazette, 3/8/1905.

89. "Great Growth of Labor Union Locals," Republican, 1/7/1903. I could find no evidence that any cereal company employees organized unions before 1902. 90. "Labor Hosts Celebrate," Gazette, 9/7/1903; "Rain at Night Marred Program," Gazette, 9/9/1903.

91. "Mill Workers' New Drill Team," Gazette, 8/19/1904. According to the Gazette, all the team members were under the age of 16.

92. Ibid.; "Big Crowd at Union Park," Gazette, 9/5/1904; "State Federation President Here," Gazette, 10/19/1904. 
Maggie Carroll served as one of the drill team leaders, helping to instill union principles of solidarity in some of the local's newest members. ${ }^{93}$ In addition, she was elected as a delegate to the union's 1904 international convention, held in Cedar Rapids, and was appointed to the convention's Constitution Committee. ${ }^{94}$ Through the establishment of Local 20, Carroll and other women unionists attempted to institutionalize a network of female mill employees, one that could help secure the gains the wrappers had achieved in 1898.

THE WOMEN who walked out of the American Cereal Company on October 22, 1898, faced great odds. In a dual-front battle, they leveraged their courage and solidarity against one of the largest, most politically powerful companies in the city and also against societal attitudes that rarely took seriously the concerns of female workers. By embracing the techniques of organized labor and using a variety of tactics to keep mill management on the defensive, the striking wrappers demanded and received support from their community and from city leaders. Like women workers elsewhere in the United States, the young women in Cedar Rapids sought not only higher wages and economic security but also dignity and respect as skilled workers. The female mill employees' ability to negotiate a successful conclusion to the strike demonstrates some of the specific advantages they enjoyed as workers in a small industrial city, including established social networks among a relatively small group of female employees;

93. “Mill Workers' New Drill Team," Gazette, 8/19/1904.

94. "International Convention of Flour and Cereal Mill Employees," Gazette, 6/20/1904; "Resolutions are Adopted," Gazette, 6/21/1904. Carroll's union career was short-lived. In August 1904 she married Robert Steel, and the couple moved to a farm to start a family. See "Marriage Licenses," Gazette, 8/24/1904; “Iowa State Census, 1925," Ancestry.com, http:/ / search.ancestrylibrary.com/, accessed 3/14/2014. None of the other strike leaders appear to have become involved in Local 20 or other labor movements in the city. The strikers' chairwoman, Myrtle Gallagher, left the American Cereal Company less than two months after the strike's end to take a position as a clerk at a dry goods store. See "Personal," Gazette, 12/10/1898. Another strike committee member, Lizzie Molloy, also was no longer employed at the mill by the end of the year. Molloy married L. M. Shields on December 26, 1898, and subsequently left the paid workforce. See "All Iowa, Select Marriages, 1809-1992," Ancestry.com, accessed 3/14/2014; Cedar Rapids City Directories (1900-1909), 1901-01-01. 
the ability to single out a new manager, a recognized stranger in the community, as responsible for newly implemented and unreasonable work demands; and widespread community concern over the American Cereal Company's perceived unfair manipulation of city tax policy. The female strikers recognized and shrewdly took advantage of opportunities to sway public opinion in their favor and paint McDonald as an unfair taskmaster. By so doing, they forced company management to listen seriously to their concerns and take steps to improve their conditions of labor, a feat attempted in the late nineteenth century by few other women workers and achieved by fewer still. 